\title{
(K)
}

Volume 16 Issue 4 Year: 2019

\section{Teacher candidates opinions on Arabic textbooks in grades 2-8}

\section{Öğretmen adaylarının 2-8 sınıflardaki Arapça ders kitaplarına ilişkin görüşleri}

\author{
Hüseyin Polat ${ }^{1}$
}

\section{Özet}

Örgün eğitimdeki ders kitapları, programların uygulanması için çok önemli bir araçtır. Programların hedeflerine ulaşmasında da büyük rol oynamaktadır. Örgün eğitimdeki yabancı dil eğitiminin başarılı olması diğer etkenlerin yanı sıra kullanılan kitaplar sayesinde olmaktadır. Ülkemizde Arapçayı yabancı dil olarak öğrenen bazı bireyler de Arapçayı öğrenmedeki sorunları çoğunlukla örgün öğretimdeki Arapça ders kitaplarında aramaktadırlar. Bu araştırmayla söz konusu sorunların tespiti ve çözüm yolları aranmıştır. Araştırma 2018-2019 eğitim öğretim yılındaki 2-8 sinıflarda kullanılan ders kitaplarını öğretmen adaylarının gözünden değerlendirilmesi ile ilgilidir. Araştırmaya söz konusu eğitim öğretim yilında Gazi Üniversitesi'ndeki 3. ve 4. sinıflarda öğrenim görmek olan 76 öğretmen adayı katılmıştır. Araştırma sonucunda Arapça ders kitaplarının iç ve dış yapı bakımından geliştirilmesi görüşü hâkim olmuştur. Kitapların birbirlerini tamamlar nitelikte olmas1, dinleme, okuma, konuşma ve yazma becerilerinin geliştirilmesi önerilmiştir.

Anahtar Kelimeler: Arapça öğretimi; Arapça ders kitaplarl; Arapça öğretmen adayları; Türkiye'de Arapça öğretimi; İlk ve ortaokullarda Arapça öğretimi.

(Extended English summary is at the end of this document)

${ }^{1}$ Doç. Dr., Gazi Üniversitesi, Yabanc1 Diller Yüksekokulu, polat312@hotmail.com 
Polat, H. (2019). Öğretmen adaylarının 2-8 sınıflardaki Arapça ders kitaplarına ilişkin görüşleri. Journal of Human Sciences, 16(4), 938-950. doi:10.14687/jhs.v16i4.5845

\section{Giriş}

Sonradan Müslüman olan ve anadili Arapça olmayan diğer milletler gibi Türkler de yüzlerce yıldır Arapçayı öğrenmeye merak salmışlardır. Bu merakın en temel nedeni şüphesiz din olgusudur. Çünkü Arapça esas olarak dini metinleri anlayıp kavrayabilmek için bir araç niteliğinde öğrenilmiştir (Özdemir, 2016; Kılıç, 2018; Yıldırım, 2017). Ancak zaman zaman ticaret, medeniyet, kültür, ikili ilişkiler vb. diğer nedenler de Arapçanın anadili Türkçe olanlar tarafindan öğrenilmesine etki etmiştir.

Türkler, Müslüman olduktan sonra bazen Arapça öğrenmek uğruna kendi dillerini ikinci plana itecek kadar Arapça öğrenme isteğine kapılmışlardır. Bu durumu Uygurlar zamanından başlayarak yüzlerce yıldır devam eden bir süreçte görmek mümkündür. Ancak özellikle yirminci yüzyılın başlarında küreselleşmeye başlayan dünyamızda Arapça dışında Fransızca, Almanca, İngilizce gibi diğer diller de Türklerin ilgisini çekmeye başlamıştır. Diğer yandan ülkemizdeki Arapça öğretimi Osmanlı döneminde olduğu gibi Cumhuriyet döneminde de devam etmiştir. Nitekim son altmış yıldan fazla bir süredir ülkemizdeki resmi kurumlarda Arapça eğitimi yapılmaktadır (Aydın, 1996; Şimşek, 2013; Soysald1, 2010).

Tarihi süreçte, günümüze gelinceye kadar anadili Türkçe olmasına rağmen Arapçayı birincil dil olarak tercih eden birçok bilim adamı Arapçayı öğretmek için birçok eseri kaleme almıştır. Bu tür bilimsel faaliyetler ülkemizde hâlâ devam etmektedir (Aydın, 2000). Türkler tarafindan kaleme alınan Arapça öğretmeye yönelik kitaplar, çoğunlukla din temelli olduğu için yüzlerce yıldır devam etmekte olan geleneğe uygun olarak gramer ağırlıklı olmuştur.

Bütün çabalara rağmen Türklerin Arapça öğrenmeleri din etkisinin dışına tam olarak çıkamamıştır. Nitekim günümüzde kültür, medeniyet, ekonomi vb. konularla ilgili yabancı dil olarak özellikle İngilizce ön plandadır. Bu durum da Arapça öğrenmedeki güdülenme durumunu olumsuz etkilemektedir.

Günümüzde Türkiye'deki Arapça öğretimi ve öğrenimi çoğunlukla muhafazakâr kesim tarafindan canlı tutulmaktadır. Bazen de din dışındaki diğer nedenlerden dolayı başta İngilizce olmak üzere Almanca, Fransızca, Rusça vb. yabanc1 dillerden sonra ikincil dil olarak ön plana çıkmaktadır. Bu nedenle modern Arapçanın öğretimi de çoğunlukla İngilizce gibi batı dillerini öğretimine bakılarak öykünme yoluyla yapılmaya çalısılmaktadır. Arapça bilgisini ölçmek için de özellikle devletin resmi sınavlarında İngilizceyi ölçme yöntemlerine bakılarak yeni ölçme teknikleri kullanılmaktadır.

Arapçanın ülkemizde öğretilmesi ve öğrenilmesinin gittikçe yaygınlaşmasının bir diğer nedeni de resmi kurumlarda İngilizce gibi yabancı dil konumunda kabul edilmesidir. Bu bağlamda akademik alanda geçerli olmakta ve ÖSYM gibi merkezi sınavlar aracılığıla ölçülüp puanlanmaktadır. Çünkü Arapça sınavlarından alınan puanlar sayesinde başta kamu sektörü olmak üzere birçok alanda daha iyi iş pozisyonları elde edebilmek mümkündür (Kllıç, 2018).

Arapçanın anadili Türkçe olanlara öğretimi konusu yüzlerce yıldır tam olarak çözülemeyen bir konudur. Çünkü bu konuda zamanın şartlarına göre yeni bazı sorunlarla karşılaşılmaktadır. Bu nedenle modern eğitim ölçütlerine göre belirlenmiş kesin bir standart oluşturulduğunu söylemek doğru olmayacaktır (Kılıç, 2018). Örgün öğretimde eğitimi yapılan diğer dillerde olduğu gibi Arapçanın da planlanmış bir öğretim programı çerçevesinde yapılması örgün eğitimin temel prensipleri gereğidir. Bu bağlamda ülkemizdeki orta dereceli okullarda Arapça eğitim programını 1973 yllından beri devam ettiği görülmektedir. Söz konusu bu programlar zaman zaman güncellenmektedir (Özcan, 2015a; Özcan, 2015b).

Arapçanın dini eğitim ağırlıkla İmam Hatip Ortaokulları ve Liselerinin dışında öğretimi konusu 1995 yllındaki Avrupa Birliği'ne üye ülkelerde gençlere en az ikinci bir yabancı dil öğretme kararından sonra başlamıştır. Buna bağlı olarak 1997-1998 eğitim-öğretim y1lında Milli Eğitim 
Polat, H. (2019). Öğretmen adaylarının 2-8 sınıflardaki Arapça ders kitaplarına ilişkin görüşleri. Journal of Human Sciences, 16(4), 938-950. doi:10.14687/jhs.v16i4.5845

Bakanlığımızca ilköğretim altıncı sınıftan itibaren ikinci bir yabancı dilin seçmeli ders olarak okutulması uygulamasına gidilmiştir (Demir, 2015; Yılmaz, 2019). Beşinci sınıftan itibaren seçmeli yabancı dil okutulmasına ise 2006-2007 eğitim-öğretim yılında başlanmışır (Seçkin, 2010).

Programların ve programların uygulanmasında aracı olan ders kitabı gibi materyallerin bilimsel ölçütlere göre incelenip değerlendirilmesi eğitimin kalitesini arttırmak için bir ihtiyaç olduğu kadar gereklidir (Arpaçukuru, 2018).

Yabancı dil öğretimi konusunda birçok yaklaşım, yöntem ve teknik bulunmaktadır (Demirel, 2014; Kılıç, 2018; Yıldırım, 2017). Yabancı dil öğretiminde özellikle I. Dünya Savaşı yıllarında ve sonrasında iletişim ön plana çıkmıstır. Çünkü savaş yıllarında galip devletlerin askerlerinin yeni alınan ya da alınması düşünülen ülkelerdeki yerel halkın dilini en kısa zamanda öğrenme ihtiyac1 doğmuştu. Bunun sonucunda da yeni karşılaşılan dil veya diller o sırada konuşuldukları şekliyle hızlı bir şekilde öğrenilmeye başlanmıştır.

Günümüzdeki 2-8 sınıflar için hazırlanmış olan Arapça öğretim programı iletişimsel yaklaşım temellidir. Bu yaklaşıma göre önemli olan dilin kurallarını açık bir şekilde öğretmek olmayıp kullanımını kavratmaktadır. Dilin iletişimi sağlayan sosyal bir olgu olduğunu savunan bu yaklaşıma göre dil öğretimi de temel olarak iletişimi sağlamalıdır.

Bu araştırmaya konu olan ders kitaplarının dayandığı Arapça eğitim programının diğer bir özelliği de sarmal olmasıdır. Sarmal dil öğretiminde öğrenilen bilgiler sonraki aşamada tekrarlanmakta ve yeni bilgiler bu tekrarların devamı niteliğindedir. Öğrenciyi merkeze alan programda öğretim aşamalı olarak yapılmaktadır (Demir, 2015). Programın ayrıca basitten karmaşığa, yakından uzağa, somuttan soyuta olmak üzere kurgulandığı savunulmaktadır. Ayrıca Diller İçin Avrupa Ortak Başvuru Metni'nden yararlanıldığ ve dinleme, konuşma, okuma, yazma gibi dört temel dil becerisine göre hazırlandığ belirtilmektedir (MEB, 2016). Dolayısıyla söz konusu programın uygulanma alanı olan ders kitaplarının da programa uygun olarak hazırlanmış olduğu varsayılmaktadır. Bazen de ders kitaplarından istenen verimliliğin arttırılmasına yönelik yardımcı materyallere ihtiyaç duyulmaktadır. Materyal geliştirme ise belirli standartlar çerçevesinde yapılmalıdır. Yapılan araştırmalara göre ders kitabında olması gereken unsurlar arasında kitabın yapısı, yöntem, amaç, öğretimin düzenlenmesi, öğretimin dayandırıldığı prensipler, alıştırmalar, öğrenciyi güdüleme ve etkin hâle getirme, metinler, dilbilgisi, sesbilim, söz varlı̆̆1 gibi özelliklerin bulunması gerekmektedir (Demir, 2015).

Tarih boyunca ülkemizde ve dünyada diğer bilim dallarında olduğu gibi yabancı dil öğretiminde de önce kitap yazılmış, program kitaba göre düzenlenmiştir. Ancak zamanla tersi yapılmaya başlanmış, önce program yapılmış, sonra da programa uygun ders kitapları yazılmaya başlanmıştır.

Geleneksel ve iletişimsel yaklaşımı temel olan yabancı dil materyalleri ve kitaplanı zamanla yaygın hale gelmiştir. Bunun üzerine geleneksel yabanc1 dil kitaplarıly iletişimsel yabanc1 dil kitapları konusunda araştırmalar ortaya çıkmıştır (Grant, 1992).

Geleneksel kitaplarda dilbilgisi çeviri yaklaşımı hâkim olduğu için gramer ağırlıklıdır. Kitaplardaki anlatım anadille yapılmaktadır. Sınav odaklıdır. Önemli olan çok kelime bilip iletişsimi sağlamak yerine dilin hatasız ve mükemmel bir şekilde kullanılmasıdır. Buna benzer birçok özelliği bulunan geleneksel yabancı dil kitapları zamanın gerektirdiği ihtiyaçlara cevap veremediği için bir süre sonra günümüzde de yaygın olarak kullanılan iletişimsel kitapların ortaya çıkmasına zemin hazırlamıştır.

İletişim temelli yabancı dil kitaplarında önemli olan iletişimdir. Dilin geçmişinden ziyade öğrenildiği andaki kullanımı, özellikle de günlük yaşamdaki kullanımı vurgulanmaktadır. Uygulama ve sonuç alma odaklıdır. Akıcı olarak kullanılması istenmektedir. Söz konusu iletişimci temele dayalı yabanc1 dil öğretimi bunun gibi daha birçok özelliğe sahip olmasına rağmen zamanla birçok eleştiriye maruz kalmıştır. Ancak bu araştırmaya konu olan ders kitaplanında da olduğu gibi hâlâ birçok yabancı dil öğretimi kitaplarında geçerliliği korumaya devam etmektedir. 


\section{2. Önem ve Amaç}

İlkokul ve ortaokullardaki araştırmaya konu olan Arapça ders kitaplarının dayandığı ders programları seçmeli dersler için hazırlanmıştır. Programın ortaokul düzeyi hazırlanırken ilkokuldayken Arapçayı seçmemiş öğrencilerin ortaokul düzeyinde seçmeleri göz önüne alınmıştır. Bu nedenle beşinci sınıftan itibaren dersi ilkokulda alan ya da almayan tüm öğrencilerin Arapçayı ilk defa öğrendikleri varsayılmıştır. Ortaokullarda zorunlu seçmeli Arapça dersinin yanı sıra diğer seçmeli yabancı dillerde olduğu gibi seçmeli olarak alınması durumunda uygulanacak olan programın seçimi Arapça zümre öğretmenlerinin kararına bırakılmıştır.

Programların ders kitaplarında karşıllk bulması eğitimin kalitesini arttıracaktır. Bu nedenle ders kitaplarının bilimsel temellere dayalı olarak araştırılması önemlidir. Günümüzde 2-8 sınıflardaki Arapça derslerinde okutulan ders kitaplarının öğretmen adayları tarafindan değerlendirme ihtiyacı da buradan kaynaklanmıştır. Araştırmaya konu olan 2-8 sinıflarda okutulan ders kitaplarına yönelik ögrretmen adaylarının görüşleriyle ilgili verilere ulaşmak için şu soruların cevapları aranmıştır:

- Ders kitapları, programlara uygun mudur?

- Ders kitapları, görsel açıdan yeterli midir?

- Ders kitaplan1, okuma-anlama becerileri bakımından yeterli midir?

- Ders kitapları, dinleme-anlama becerileri bakımından yeterli midir?

- Ders kitapları, yazma becerileri bakımından yeterli midir?

- Ders kitapları, konuşma becerileri bakımından yeterli midir?

- Ders kitapları, tüm sinıflar için bir silsileyi takip etmekte midir?

- Ders kitapları, dil edinimine uygun olarak hazırlanmış mıdır?

\section{Yöntem}

Araştırmada yazılı ve görsel belgelerin derinlemesine incelenmesine yardımcı olan nitel araştırma yönteminin içerik analizi tekniğinden yararlanılmıştur (Ary vd., 2006:95-102). Çalışmada elde edilen nitel veriler bu teknikle sayısallaştırılarak verilmiştir.

Veriler, Gazi Üniversitesi Arapça Öğretmenliği Anabilim Dalı'nda okumakta olan üçüncü ve dördüncü sınıftaki öğrencilerin anket sorularına vermiş oldukları cevaplar yoluyla toplanmıştır. Araştırma örnekleminde yer alan öğretmen adayları öğretmenlik uygulaması dersi çerçevesinde ilk ve ortaokullarda uygulama stajı yapan öğrencilerden oluşmuştur. Anket uygulamasından önce araştırmaya konu olan ders kitapları, bir eğitim dönemi boyunca araştırmaya katılan öğretmen adaylarıyla sınıf ortamında yansı kullanılarak haftada 3 saat olmak üzere değerlendirilmiştir. Ankete katılan öğretmen adaylarının yaş ortalamaları genellikle birbirlerine yakın olduğu ve cinsiyet bakımından da sadece on kişi erkek, diğerleri bayan olduğu için araştırmada ayrıca demografik durum belirtilmemiştir. Ankette katıllyorum, katılmıyorum, kısmen katıllyorum gibi üçlü likert ölçeğinin yanı sıra adayların araştırma konusuyla ilgili anket sorularının dışındaki görüşlerine belirtmelerine yönelik bir adet de açı uçlu soru sorulmuştur. Anket uygulaması araştırmacı tarafindan bizzat yürütülmüştür. Anket soruları alanında uzman 5 akademisyen ve 15 öğretmenin görüsslerine başvurularak hazırlanmışıı. Araştırmaya toplam 76 öğretmen adayı katılmıştır. Başka bir ifadeyle örneklemdeki tüm bireyler araştırmaya katılmıştır.

\section{Bulgular ve Yorumlar}

Araştırmaya katılan öğretmen adaylarının 2018-2019 eğitim-öğretim yllında Milli Eğitim Bakanlı̆ğ'na bağlı devlet okullarındaki 2-8 sinıflarda okutulmakta olan Arapça kitaplarıyla ilgili görüşleri şu şekildedir: 
Polat, H. (2019). Öğretmen adaylarının 2-8 sınıflardaki Arapça ders kitaplarına ilişkin görüşleri. Journal of Human Sciences, 16(4), 938-950. doi:10.14687/jhs.v16i4.5845

Tablo 1: Ders kitaplar1, programlara uygundur.

\begin{tabular}{l|l|l|l|l|l|l}
\hline Katıliyorum & $f \%$ & Katilmiyorum & $f \%$ & Kismen & $f \%$ & Toplam \\
\hline 32 & 42,105 & 2 & 2,631 & 42 & 55,263 & 76 \\
\hline
\end{tabular}

Araştırmaya katılan öğretmen adaylarından yaklaşı yüzde kırk ikisi ders kitaplarının Milli Eğitim Bakanlığı'nın 2018-2019 eğitim-öğretim yllında 2-8 sınıflar için uygulanmasını istediği Arapça öğretim programlarına uygun olduğunu ifade etmiştir. Bu araştırma yapılmadan önce bir ders yll dönemi içerisinde haftada 3 saat olmak üzere araştırmaya katılan öğretmen adaylarıyla söz konusu Arapça öğretim programı grup halinde incelenmiştir. Araştırmaya katılan öğretmen adaylarından yaklaşık yüzde üçlük kısmı Arapça öğretim programı ile ders kitaplarının uyum içinde olmadığını belirtirken yaklaşı yüzde elli beşlik kısmı kısmen uyduğu yönünde görüş belirtmiştir. Tablodan da anlaşıldığı üzere araştırmaya konu olan ders kitapları Arapça öğretim programlarıyla genel olarak uyum içindedir.

Tablo 2: Ders kitapları görsel açıdan yeterlidir.

\begin{tabular}{l|l|l|l|l|l|l}
\hline Katiliyorum & $f \%$ & Katilmiyorum & $f \%$ & Kismen & $f \%$ & Toplam \\
\hline 20 & 26,315 & 16 & 21,052 & 40 & 52,631 & 76 \\
\hline
\end{tabular}

Arapçanın ilkokul ikinci sınıftan itibaren öğretilmesi sürecinde öğrencinin yaşları ve alg1 durumları göz önüne alındığında görsel iletilerin çok önemli olduğunu belirtmek gerekir. Bu nedenle araştırmaya konu olan ders kitaplarının görsellik açısından yaşlarına ve birikimlerine uygun olup olmadığını tespit etmek için araştırmaya katılan öğretmen adaylarından görüşlerini belirtmeleri istenmiştir. Tabloda da görüldüğü üzere araştırmaya kattlan öğretmen adaylarından yaklaşık yüzde yirmi altısı kitapların görsel açıdan yeterli olduğunu, yaklaşı yüzde yirmi biri yeterli olmadığını, yaklaşık yüzde elli üçü ise kısmen yeterli olduğunu belirtmiştir.

Tablo 3: Ders kitapları, okuma-anlama becerileri bakımından yeterlidir.

\begin{tabular}{l|l|l|l|l|l|l}
\hline Katıliyorum & $f \%$ & Katilmiyorum & $f \%$ & Kismen & $f \%$ & Toplam \\
\hline 32 & 42,105 & 10 & 13,157 & 34 & 44,736 & 76 \\
\hline
\end{tabular}

Günümüzde birey, adilini öğrenirken okuma etkinliğine genellikle örgün öğrenim çağ1 olan ilkokul döneminde başlamaktadır. Örgün öğretim öncesi okuma etkinliği de yapılmış olsa da yoğun bir okuma faaliyeti çoğunlukla okul çağındadır. Ancak yabancı dil öğrenirken okum faaliyetini zaten kendi anadilinde beceri haline dönüştürmüş olarak hazır olduğu için yabancı dildeki okuma işine anadilindeki gibi uzun bir zaman sonra başlamamaktadır. Diğer yandan Türkçe ve Arapçada olduğu gibi bireyin anadili ile öğrenmeyi hedeflediği yabancı dilin alfabe ve yazısının hem şekil hem okunuş hem de yazma yönünün farklı olduğu durumlarda yabancı dilde okuma çok daha fazla önem arz etmektedir. Nitekim anadili Türkçe olan bireyler Arapçayı, Özellikle de harekeleme sistemi olmayan Arapça metinleri okurken oldukça zorlanmaktadır. Bazen harekeli metinleri çok iyi okuyup anlayabilen bireyler dahi hareke sistemi olmayan Arapça metinleri okumakta zorlanmaktadırlar. 
Polat, H. (2019). Öğretmen adaylarının 2-8 sınıflardaki Arapça ders kitaplarına ilişkin görüşleri. Journal of Human Sciences, 16(4), 938-950. doi:10.14687/jhs.v16i4.5845

Okuma metinleri yazılı olduğu için önemli olduğu kadar yabanc1 dil öğrenen bireyin öğrenmeyi hedeflediği dildeki sözcük dağarcığı ve dilbilgisi düzeyine uygun olup olmadı̆ı da önemlidir. Bu nedenle araştırmaya katılan öğretmen adaylarına araştırmaya konu olan kitapların okuma-anlama açısından değerlendirilmesi konusunda görüşlerine başvurulmuştur. Tabloda da görüldügü üzere araştırmaya katılan adaylardan yaklaşık yüzde kırk ikisi ders kitaplarının okuma-anlama becerisi bakımından uygun olduğunu, yaklaşık yüzde on dördü uygun olmadığını, yaklaşık yüzde kırk beşi ise kismen uygun olduğunu belirtmiştir.

Tablo 4: Ders kitapları, dinleme-anlama becerileri bakımından yeterlidir.

\begin{tabular}{l|l|l|l|l|l|l}
\hline Katiliyorum & $f \%$ & Katilmiyorum & $f \%$ & Kismen & $f \%$ & Toplam \\
\hline 24 & 42,105 & 18 & 23,684 & 34 & 44,736 & 76 \\
\hline
\end{tabular}

Herhangi bir işitme sorunu bulunmayan insanlar yaşadıkları dünyadaki sesleri henüz anne karınlarındayken duymaya başlamaktadırlar. Doğduktan sonra da genellikle yoğun bir ses verisine maruz kalmaktadırlar. Konuşma yetenekleri sayesinde duymuş oldukları bu sesler bir süre sonra belleklerinde gruplandırılmaktadır. Taklit yetenekleri sayesinde de duydukları sesleri konuşma olarak yansıtmaktadırlar. Ancak taklit etmiş oldukları seslerin gerçek anlamda kurallar bütünü şeklinde dil hâline dönüşmesi için genellikle birkaç yıl geçmesi gerekmektedir. Anadili olarak edinilen bu süreç bireylerin maruz kaldıkları dil ya da dillerin yoğunluğuna, çevre şartlarını, bellek ve yetenekleri gibi birçok nedene bağlıdır. Yabancı dil öğreniminde ise bireyler yabancı dili, yeni dilin ses verilerine maruz kalmaları oranı ölçüsünde kavrayabilmektedirler. Anadili öğreniminde olduğu gibi yabancı dil öğreniminde de dinlenilenlerin anlamlandırılmasında birçok etken bulunmaktadır. Anadili öğrenirken yoğun ses verileriyle karşılaştıkları halde anadillerinin yapılarını tam olarak kavrayabilmek için yıllara ihtiyaç duymaktadırlar. Oysa yabancı dil öğrenirken dinleme verileri çoğu zaman, özellikle de öğrenilmesi hedeflenen yabancı dilin anadili olarak konuşulmadığ1 bir ortamda öğrenilmesi durumunda çok seyrektir. Bu durumda bireyler önceki dil yaşantılarından yararlanarak dinlediğini anlama sürecini kısaltmaya çalışmaktadırlar. Bu nedenle neyin ne kadar dinleneceği önemlidir. Zaman sınırlıdır. Yabancı dil öğretiminde araç durumundaki ders kitaplarında yer alan dinleme etkinliklerinin seçimi ve uygulanması böylece daha fazla önem kazanmaktadır. Bu araştırmada, araştırmaya katılan öğretmen adaylarının görüşleri araştırmaya konu olan ders kitaplarının geliştirilmesine katkı sağlayacağı için katılımcılara ders kitaplarındaki dinleme-anlama becerilerinin Arapçanın öğrenilmesi için yeterli olup olmadığ sorulmuştur. Dördüncü tablodan da anlaşılacağ1 üzere katılımcıların yaklaşık yüzde kırk ikisi yeterli olduğunu, yaklaşık yüzde yirmi dördü yeterli olmadığını, yaklaşık yüzde kırk beşi ise kısmen yeterli olduğunu ifade etmişlerdir. Buradan da söz konusu ders kitaplarındaki dinleme-anlama becerilerine yönelik çalısmaların geliştirilmesi gerektiği anlaşılmaktadır.

Tablo 5: Ders kitapları, yazma becerileri bakımından yeterlidir.

\begin{tabular}{l|l|l|l|l|l|l}
\hline Katıliyorum & $f \%$ & Katilmiyorum & $f \%$ & Kismen & $f \%$ & Toplam \\
\hline 26 & 34,210 & 12 & 15,789 & 38 & 50 & 76 \\
\hline
\end{tabular}


Yabancı dil öğrenirken dinleme ve okuma yoluyla belleğe alınan veriler konuşma ve yazma olarak dışa vurulmaktadır. Konuşma sırasında geri dönüt, anlık düzeltme, kişinin ses ve dil yapısı gibi bazı etkenlerden dolayı bellekteki bilgilerin ifade edilmesi bazen istenilen düzeyde olmayabilir. Ancak yazı yoluyla dışa vurma sırasında düzeltme imkânları daha fazla olmaktadır. Birey öğrendiği yabancı dilin dilbilgisi kuralları ve sözcük bilgisi gibi görsel, duyuşsal ve bilişsel durumlarını yazı yoluyla gösterme imkânına sahip olmaktadır. Bu nedenle diğer yabancı dillerin öğreniminde olduğu gibi Arapçanın öğretimi sırasında da yazılı ifade önemlidir. Ancak burada söz konusu olan mükemmel bir yazılı ifade olmamalıdır. Basitten karmaşığı aşamalı olarak gerçekleştirilen bir süreç söz konusudur. Bu nedenle araştırmaya katılan öğretmen adaylarına araştırmaya konu olan kitaplardaki Arapça yazılı ifadenin durumu konusundaki görüşleri sorulmuştur. Beşinci tabloda da görüleceği üzere katılımcılardan yaklaşık yüzde otuz dördü yetersiz olduğunu, yaklaşı yüzde on altısı yeterli olduğunu ve yaklaşı yüzde ellisi ise kısmen yeterli olduğunu belirtmiştir. Diğer yandan Arapçanın yazılı anlatımının yanı sıra yazı simgelerinin durumu da bazen sorun oluşturabilmektedir. Çünkü Arapça sağdan sola yazılmakta olup alfabesinin yazımı Türkçedekinden farklı olarak resim yazısını kullanan alfabeler grubunda yer almaktadır. Başka bir ifadeyle Türkçe gibi Latin bazlı alfabelerdeki harflerin birbirleriyle birleşmeleri isteğe bağliyken ebced yazısı temelli alfabelerdeki harflerden çoğu kendisinden önceki ya da bazen sonraki harflerle birleşmek zorundadır. Ancak Arapçanın yazım şekli bu araştırmada konu edilmemiştir.

Tablo 6: Ders kitapları, konuşma becerileri bakımından yeterlidir.

\begin{tabular}{l|l|l|l|l|l|l}
\hline Katıliyorum & $f \%$ & Katılmiyorum & $f \%$ & Kismen & $f \%$ & Toplam \\
\hline 8 & 10,526 & 34 & 44,736 & 34 & 44,736 & 76 \\
\hline
\end{tabular}

Konuşma becerisi anadilde olduğu gibi yabancı dil öğrenirken de önemlidir. Bireyler kendi anadillerinde bazen yabancı birisiyle konuşmaları sırasında sıkıntılar yaşayabilmektedirler. Sonradan öğrenilen yabancı bir dili kullanırken de bazı içsel engeller olabilmektedir. Birey öğrenmekte olduğu yabancı dili, o dili anadili olarak konuşan bireylerle konuşurken yanlsş yapma korkusuyla çekinebilmektedir. Öğrendiği yabancı bir dili kendisi gibi sonradan öğrenmekte olan yakınlarıla ya diğer kişilerle konuşurken yapmacık olma endişesi taşıdığı için kullanmaktan çekinebilmektedir. Özellikle bu araştırmaya konu olan hedef kitlenin geçmiş yaşantıları, yetişmekte oldukları ortamları ve dünya görüşlerinin biraz daha konservatif olduğu göz önüne alındığında kendilerini Arapça olarak ifade etmeleri çok kolay olmayacaktır. Diğer yandan araştırmaya katılan öğretmen adaylarının çoğu da İmam Hatip Lisesi mezunu olmalarının yanı sıra Gazi Üniversitesi Arapça Öğretmenliği Anabilim Dalı'nda bir yılı yoğunlaştırılmış Arapça hazırlık sınıfı olmak üzere en az dört yıl Arapça öğrenmişlerdir. Ancak buna rağmen Arapça konuşurken zorlanmaktadırlar. Bütün bunlar göz önüne alındığında araştırmaya konu olan ders kitaplarının konuşma becerisini geliştirmeye yönelik yeterliliği daha çok önem kazanmaktadır. Bu nedenle öğretmen adaylarına araştırmaya konu olan ders kitaplarındaki Arapça konuşma becerilerine yönelik düşünceleri sorulmuştur. Altıncı tabloda da görüldüğü üzere adayların yaklaşı yüzde on biri ders kitaplarının konuşma becerilerini geliştirme bakımından yeterli olduğunu, yaklaşık yüzde kırk beşinin yetersiz olduğunu ve yaklaşık yüzde kırk beşinin de kısmen yeterli olduğunu düşündükleri tespit edilmiştir. 
Polat, H. (2019). Öğretmen adaylarının 2-8 sınıflardaki Arapça ders kitaplarına ilişkin görüşleri. Journal of Human Sciences, 16(4), 938-950. doi:10.14687/jhs.v16i4.5845

Tablo 7: Ders kitapları, tüm sınıflar için bir silsileyi takip etmektedir.

\begin{tabular}{l|l|l|l|l|l|l}
\hline Katıliyorum & $f \%$ & Katilmiyorum & $f \%$ & Kismen & $f \%$ & Toplam \\
\hline 22 & 28,947 & 10 & 13,157 & 24 & 31,578 & 76 \\
\hline
\end{tabular}

Öğrenmede devamlılık önemlidir. Çünkü kesintili öğrenme sırasında bir bütünlük olmadığı için önceden öğrenilen ile sonradan öğrenilecek arasında bağ kurmada sorun olabilmektedir. Öğrenme sırasındaki aralığın fazla olması bazen öğrenme güdülenmesini de olumsuz yönde etkilemektedir. Özellikle yabancı dil öğrenmede öğrenilenlerin pekiştirilip yeni bilgilerin eklenmesi açısından kesintisiz bir süreç çok daha önemlidir. Yabancı dilde öğrenilenlerin belirli bir silsile içinde devam etmesi bilgiler arasında bağ kurmayı ve öğrenilenlerin pekişmesi gibi birçok nedenlerden dolayı gereklidir. Bu nedenle araştırmanın örneklemindeki öğretmen adaylarına araştırmaya konu olan ders kitaplarında tüm sınıflar için bir silsilenin takip edilip edilmediği konusundaki görüşleri sorulmuştur. Yedinci tablodan da anlaşılacağı üzere araştırmaya katılan öğretmen adaylarından yaklaşık yüzde yirmi dokuzu ders kitaplarında bir silsile olduğunu, yaklaşık yüzde on üçü bir silsile olmadığını ve yaklaşık yüzde otuz ikilik bölümü ise kısmen bir silsile olduğunu belirtmiştir.

Tablo 8: Ders kitapları, dil edinimine uygun olarak hazırlanmıştır.

\begin{tabular}{c|l|l|l|l|l|l}
\hline Katıliyorum & $f \%$ & Katilmiyorum & $f \%$ & Kismen & $f \%$ & Toplam \\
\hline 12 & 15,789 & 26 & 34,210 & 38 & 50 & 76 \\
\hline
\end{tabular}

Dil edinimi genel olarak bireyin anadilini edindiği dil için geçerlidir. Ancak özellikle iki dillilerde olduğu bazen ikinci dilin edinilmesi de söz konusudur. Özellikle uzun zamandan beri yabanc1 dil öğretiminde önemli yer tutan iletişimsel yaklaşımda yabancı dilin anadili edinimi gibi doğal ortama yakın bir durumda öğrenilmesi öngörülmektedir. Bu nedenle araştırmaya konu olan ders kitaplarının incelenmesi sırasında araştırmaya katılan öğretmen adaylarına ders kitaplarının dil edinimine uygun olarak hazırlanıp hazırlanmadığı konusundaki görüşleri sorulmuştur. Katılımcıların tamamı öğrenim hayatları boyunca dil edinimi dersini görmüş olan bireylerden oluşmaktadır. Sekizinci tablodan da anlaşlacağı üzere öğretmen adaylarından yaklaşık yüzde on altısı araştırmaya konu olan ders kitaplarının dil edinimine uygun olduğunu, yaklaşık yüzde otuz dördü uygun olmadığını ve yaklaşık yüzde ellisi ise kısmen uygun olduğunu belirtmiştir.

\section{Tablo 9: Diğer Görüşleriniz}

Nicel alandaki bilimsel araştırmalar sırasında her ne kadar araştırmacı tarafindan kurallar çerçevesinde bazı teknikler kullanılarak sonuçlara ulaşılmaya çalışılsa da bazen araştırmacının ihmal ettiği durumlar bulunabilmektedir. Bu araştırmada olduğu gibi araştırmaya katılanların kendilerine sunulan anket soruları dışındaki konularla ilgili görüşlerine başvurulması önemlidir. Araştırmaya katılan öğretmen adaylarının araştırmaya konu olan ders kitaplarıyla ilgili anket soruları dışındaki görüşleri şu şekilde sıralanmışır:

- Kitaplar daha renkli olabilir.

- Üniteler birbirini tamamlar nitelikte değildir.

- Daha fazla öğrenci odaklı olabilir. 
- 8. sınıftaki ders kitabı programdaki kazanımlarla uyumlu değildir.

- 2. ve 3. sinıflardaki harf tekrarları fazladır.

- 6. sınıf resimleri biraza daha dikkat çekici olabilir.

- 2. ve 3. sınıfta genel olarak harf öğretimi etkinlikleri ve boyama bulunmakta olup tekrar fazlalı̆̆1 söz konusudur. Alıştırmalar farklı etkinliklerle zenginleştirilebilir.

- 6. sınıfın kitabı içerik bakımından diğer sınıflara göre daha ağırdır.

- Kitaplardaki şarkı etkinliği yetersizdir.

- 2. ve 3. sınıflarındaki kitaplarda dinleme ve konuşma etkinliği arttırılabilir.

- Tekrarlara gereğinden fazla yer verilmiştir.

- Dinleme anlama becerisiyle ilgili alıştırmalar yetersizdir.

- Her ünitenin sonunda bir şarkı eklenmesi pekiştirme açısından yararlı olacaktır.

- Kitaplar çizgi filmler, ses kayıtları ve farklı oyunlarla desteklenmelidir.

- Tiyatro, canlandırma ve küçük yarışmalar eklenerek konuşma becerisi desteklenmelidir.

- 5. ve 6. sınıf kitapları öğrencilerin ilgilerini çekme bakımından yetersizdir.

- Sözlü anlatım becerisini geliştirecek daha fazla etkinlik olmalıdır.

- Yazma becerisini geliştirmeye yönelik etkinlikler arttırılmalıdır.

- Her ünitenin sonunda bazı sorularla ünite tekrarı yapılmalıdır.

- Öğrenciyi derse katmaya yönelik etkinliklere daha çok yer verilmelidir.

- Görsel açıdan zenginleştirilebilir.

- Dinle ilgili konuların azaltılması yerinde olacaktır.

- Dil edinimi açısından yeterli değildir. Bu da Arapçayla ilgili bilgilerin kalıcı olmasını engellemektedir.

- Kitaplar tasarım açısından gözden geçirilip sıkıcı olma durumundan kurtarılmalıdır.

- Öğrenci merkezli yeni etkinlikler eklenmelidir.

- Konular bakımından öğrencinin dikkatini çekecek konulara yer verilmelidir.

- Video linkleri eklenebilir.

- Konu yoğunlukları eşit olmayıp her sınıf için farklı düzeydedir.

- Gramer konularının birbirini tamamlar nitelikte olması gerekir.

- Grup çalışmasına daha fazla yer verilmelidir.

\section{Sonuç ve Öneriler}

Ülkemizdeki Arapça öğretimine yönelik yapılan araştırmalar, Arapça öğretiminde hedeflerin gerçekleşemediğini göstermektedir (Altun, 2017; Yıldırım, 2017). Özellikle Cumhuriyet dönemindeki Arapça öğretiminin yetersizliği bilimsel eleştiriler konu olmaya devam etmektedir (Soyupek, 2004). 
Yabancı dil öğretimindeki teknikler çeşitlidir. Buna yönelik seviye tespit yapılarak sınıflar/gruplar oluşturulması, dilbilgisi ile metin bilgisinin aynı zamanda gerçekleştirilmesi, sessiz okuma, güdüleyici metinlerin seçimi, kelime öğretimi, oyunlara başvurulması, standart kartların oluşturulması gibi birçok teknik tavsiye edilmektedir (Gündüzöz, 2010; Yıldırım, 2017; Aydın, 2014; Aksungur, 1997; Ekmekçi ve Ekmekçi, 1980; Dağbaşlı, 2007; Coşkun, 2008; Gömleksiz, 2005: Batd1, 2012; Aslan, Coşkun, 2016). Eğitimdeki güdülemeyi arttıran materyal tasarımı bu açıdan öğrenmeyi kolaylaştırmaktadır (Kılıç, 2018). Özellikle başlangıç düzeydeki öğrenci, yabancı bir dili öğrenirken yeni kelimelerin listesine ulaşmak istemektedir. Böyle bir listesinin bulunmaması öğrencinin öğrenmekte olduğu yabancı dili öğrenirken zorlanmasına neden olacaktır (Kılıç, 2018).

Diğer yabancı diller için olduğu gibi Arapça için de öncelikle yabancı dili öğrenmeyi bilmek gerekir. Arapçayı Türkiye'de, başka bir ifadeyle Arapçanın resmi olarak konuşulmadığı bir ülkede öğrenirken günün getirdiği iletişim araçlarından yararlanmanın yanı sıra aktif öğrenme, öğrenilenleri pekiştirme, verimli ve kesintisiz çalışma, bilgileri parçalar hâlinde öğrenme, dinleme, okuma ve anlatma etkinliklerinde bulunma gibi tekniklerin yararlı olacağı düşünülmektedir (Doğan, 2008).

Eğitim programının uygulanmasında ders kitaplarının yanı sıra teknolojinin güncel imkânlarından yararlanarak işitsel ve görsel araç gereçler gibi farklı ders materyallerini geliştirmek de mümkündür. $\mathrm{Bu}$ materyaller hem programın hem de ders kitaplarının gerektirdiği kazanımlara ulaşmada çoğu zaman kilit rol oynayacaktır.

$\mathrm{Bu}$ araştırmadaki birinci tabloda da belirtildiği üzere araştırmaya konu olan ders kitapları Arapça öğretim programıyla genel olarak uyum içindedir. Ancak ikinci tabloya bakıldığında ders kitaplarının görsel açıdan zenginleştirilmesinin yerinde olacağı kanaatine varılmıştır. Üçüncü tablodan anlaşıldığına göre ders kitaplan, öğrencinin okuma-anlama becerisini geliştirmesi açısından zenginleştirilmesi gerekmektedir. Dördüncü tablodan anlaşıldığına göre ders kitapları dinlemeanlama becerisini geliştirme açısından istenen düzeyde değildir.

Yabancı dil öğrenen bireyin bildiklerini ortaya koyacağı iki temel yol bulunmaktadır. Bunlardan birisi konuşma, diğeri ise yazmadır. Beşinci ve altıncı tablodan anlaşılacağı üzere araştırmaya konu olan ders kitapları konuşma ve yazma becerisini geliştirme açısından yeterli düzeyde değildir.

Araştırmayla elde edilen sonuçlara göre 2-8 sınıfları için yazılacak programlarla ilgili olarak şu önerilerde bulunmak mümkündür:

- Arapça eğitim programları ile eğitim sırasında uygulama araçlarından en önemlisi olan ders kitaplarının mümkünse aynı kişi veya kişiler tarafindan yazılması daha uygun olacaktır.

- Ders kitaplarının günümüz teknolojisine uygun olarak donatılması yerinde olacaktır.

- Ders kitaplarındaki görsellik önemlidir. Özellikle ilkokulda okuyan öğrenciler için dikkatlerini daha çok çekecek görsellerin bulunduğu kitapların yazılması gerekir.

- Günümüzde hızla gelişen iletişim araçlarının başında internet ve sanal ortam gelmektedir. Öğrenme de bunan paralel olarak günümüz şartlarına uygun hale getirilmelidir. Genelde yabancı dil eğitimi, özelde ise Arapçanın eğitimi sırasında sanal araç ve gereçlerden yeterince yararlanmak yerinde olacaktır.

- Arapçanın ilk ve ortaokullarda öğretimi konusunda bakanlığın karar vermesi gereken konuların başında öğrencinin ikinci sınıfta seçmeye başladığı yabancı dili daha sonraki sınıflarda değiştirmemesidir. 
Polat, H. (2019). Öğretmen adaylarının 2-8 sınıflardaki Arapça ders kitaplarına ilişkin görüşleri. Journal of Human Sciences, 16(4), 938-950. doi:10.14687/jhs.v16i4.5845

\section{Kaynaklar}

Aksungur, S. T. (1997). Using games in language teaching, In Teaching Factor in Foreign Language Classes, First International Tömer Conference, Tömer Gaziantep Branch, June 6-7 1997, s.30-43.

Altun, A. (2017). Türklere Arapşa Öğretim Yöntem ve Teknikleri: Sorunlar ve Çözü̈ler, Akdem Yayınları: İstanbul.

Arpaçukuru, O. (2018). Arapça dersi öğretim programının uygulanmasına yönelik bir alan araştırması (Tekirdağ İli / Süleymanpaşa İlçesi Örneği), tasavvur tekirdă̆ ilahiyat dergisi, C.4, S.1, s.167-190.

Ary, D.; Jacobs, L. C.; Sorensen, C.; Razevieh, A.. (2006). Introduction to research in education. Wadswort:Belmont, USA.

Aslan, E.; Coşkun, O. (2016). Yabancılara Türkçe öğretiminde oyun yazıllımları ile sözcük öğretimi. Turkish Studies, C. 11/3, s.221-236.

Aydın, M. Z. (1996). Eğitimde program geliştirme ve Arapça dersi öğretim programı üzerine, Cumburiyet Üniversitesi İlabiyat Fakültesi Dergisi 1/1 s.123-142.

(2000), “Arapçayı Nasıl Öğretelim?”, Din Öğretiminde Yeni Yaklassımlar, Der. Mualla Selçuk, Mili Eğitim Bakanlığı:İstanbul, s. 53-68.

Aydın, T. (2014). Dil öğretimi ve oyun - çoklu zekâ teorisi 1şı̆̆ında - Dinbilimleri Akademik Arastrma Dergisi, C.14, s.71-3.

Batdı, V. (2012). Yabancı dil öğretiminde eğitsel oyunların kullanılmasına ilişkin öğretmen görüşleri. Ë̈itim ve Ögretim Araştırmalar Dergisi, C.1, S.4, s.317-324.

Coşkun, H. (2008). Türkiye'de ikinci yabancı dilin oyun yoluyla etkili öğretimi, Sosyal Bilimler Enstitüiü Dergisi, S.1, s.73-89.

Dağbaşl1, G. (2007). Oyun tekniği ve Arap̧̧a ögretiminde kullanmm, Yüksek Lisans Tezi, Gazi Üniversitesi Ĕ̆itim Bilimleri Enstitüsü, Ankara.

Demir, M. (2015). Illkögretim 4. ve 5. sminf Arap̧̧a dersi ögretim programmm ve ders materyallerinin değerlendirilmesi, Doktora Tęৃ, Gąi Üniversitesi Eğitim Bilimleri Enstitüsü, Ankara.

Demirel, Ö. (2014). Yabancı dil ögretimi: Dil pasaportu, Dil biyografisi, Dil dosyası, Pegem Akademi:Ankara 2014.

Doğan, C. (2008). Arapça öğrenmeyi öğrenmek ya da iyi bir Arapça öğrencisi olmak, Harran Üniversitesi İlahiyat Fakëlltesi Dergisi, S.6, s.103-123.

Ekmekçi, F. Ö.; Ekmekçi M. T. (1980). Yabancı dil öğretiminde benzetleme ve oyun etkinliği, IZLEM Yabancı Dil Ögretimi Dergisi, 4, 1980, s.20-25.

Gömleksiz, M. N.(2005). Oyun ile İngilizce öğretiminin uygulanması ve öğrenci bașarısına etkisi (Elazı̆̆ Özel Bilgem İlköğretim Okulu örneği), Kirgızistan-Türkize Manas Üniversitesi Sosyal Bilimler Dergisi, C.7, s.179-195.

Grant, N. (1992). Making the most of your textbook: Langman Keys to Language Teaching, England, Longman.

Gündüzöz, S. (2010). Arapça öğretiminde başvurulacak bazı yöntem ve teknikler - pedagojik bir değerlendirme, Ondokuz. Mayıs Üniversitesi, İlabiyat Fakültesi Dergisi, S.29, s.35-53.

Kaya, Z. (2006). Öğretim teknolojileri ve materyal gelistirme, Pegem A Yayıncillk:Ankara.

Kulıç, R. (2018). Arapşa okuma dil becerisinde materyal tasarmm ve kullanım (özel amaçh dil eğitim ve ögretim örneği), Yüksek Lisans Tezi, Hitit Üniversitesi Sosyal Bilimler Enstitüsü, Çorum.

MEB (2016). İlköğretim Arapça Dersi (2,3,4,5,6,7 ve 8. Sınıflar) Öğretim Programı (Değişiklerle Birlikte), Ankara.

Özcan, M. (a) (2015). Mesleki Arapça dersi öğretim programına yönelik öğretmen görüşleri. Dil ve Edebiyat Dergisi, S.14, s. 52-76.

Özcan, M. (b) (2015). Türkiye'de ve Dünyada Arapça öğretimi için müfredat geliştirme çalışmaları ve ilköğretim Arapça dersi müfredatı için bazı öneriler, International Journal of Science Culture and Sport (IntJSCS) 4, s.81-94. 
Polat, H. (2019). Öğretmen adaylarının 2-8 sınıflardaki Arapça ders kitaplarına ilişkin görüşleri. Journal of Human Sciences, 16(4), 938-950. doi:10.14687/jhs.v16i4.5845

Özdemir, S. (2016). Arapça sözlü anlatım eğitimi. Amasya Üniversitesi İlabiyat Fakültesi Dergisi, C.3, S.6, s.47-53.

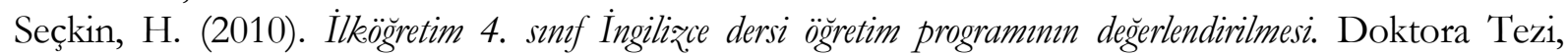
Hacettepe Üniversitesi Sosyal Bilimler Enstitüsü, Ankara.

Şimşek, S. (2013). Öğretim programları açısından İmam Hatip Liselerinde Arapça öğretiminin tarihi süreci, Imam Hatip Liselerinde Arap̧̧a Ögretimi Semposyumu (Istanbul, 24-25 Arahk 2011), Akdem Yayınlar1:İstanbul.

Soysald1, M. (2010). Türkiye'deki İlahiyat Fakültelerinde Arapça öğretiminde karşılaşılan problemler ve çözüm yolları, EKEV Akademi Dergisi 14/45, s.247-279.

Soyupek, H. (2004). İkinci Meşrutiyet'ten Günümüze Türkiye'de Arapşa Ögretimi, Doktora Tezi, Süleyman Demirel Üniversitesi Sosyal Bilimler Enstitüsü, Isparta.

Yıldırım, T. (2017). Yabancı dil olarak Arap̧ca ögretiminde eğitsel oyun yöntemi, Yüksek Lisans Tezi, Fatih Sultan Mehmet Vakıf Üniversitesi Sosyal Bilimler Enstitüsü, İstanbul.

Yılmaz, H (2019). el-Yâsemîn" isimli Arapça öğretim setinin biçimsel ve yöntemsel açıdan değerlendirilmesi. Journal of Human Sciences, 16(3), s.857-874

\section{Introduction}

\section{Extended English Summary}

Today, courses that are based on primary and secondary school textbooks in Arabic which is the subject of research in Turkey was prepared for elective courses. While preparing the secondary school level of the program, it was taken into consideration that the students who did not choose Arabic at primary school were chosen at the secondary school level. For this reason, it is assumed that all students who took or did not take the course from the fifth grade learned Arabic for the first time. In addition to compulsory elective Arabic in secondary schools in the case of elective as in other foreign languages the choice of the program to be implemented is left to the decision of the Arabic group teachers

If the programs are found response in the textbooks, the quality of education will increase. For this reason, it is important to research textbooks on a scientific basis. In this study, the answers of the following questions were sought in the evaluation of Arabic textbooks for 2-8 grades in Arabic schools by the Ministry of National Education in 2018-2019:

-Are textbooks suitable for programs?

-Are textbooks visually sufficient?

- Are textbooks sufficient for reading and comprehension skills?

- Are textbooks sufficient for listening-comprehension skills?

- Are textbooks sufficient for writing skills?

- Are textbooks sufficient for speaking skills?

- Do textbooks follow a sequence for all classes?

- Are the textbooks prepared in accordance with language acquisition?

\section{Method}

In this study, content analysis technique of qualitative research method, which helps to examine the written and visual documents in depth, was used. Qualitative data obtained in this study were transferred by digitizing with this technique. The data were collected by the answers of the third and fourth year students who are studying at the Department of Arabic Language Teaching at Gazi University. The pre-service teachers in the research sample consisted of preservice teachers internships in primary and secondary schools within the framework of teaching practice course. Before the questionnaire, the textbooks subject to the research were evaluated for 3 hours a week by using reflections in the classroom environment with the prospective teachers who participated in the research during an educational period. As the average age of the prospective 
teachers was generally close to each other and only ten people were male and the others were female, the demographic status was not indicated in the study. In addition to the three-point Likert scale such as agree, disagree, partially agree, one open-ended question was asked for the candidates to state their views outside the survey questions. The survey was conducted by the researcher herself. The questionnaire was prepared by asking the opinions of 5 academicians and 15 teachers. A total of 76 prospective teachers participated in the study. In other words, all individuals in the sample participated in the study.

\section{Data Analysis}

Approximately forty-two percent of the prospective teachers stated that the textbooks were in accordance with the Arabic curriculum that the Ministry of National Education wanted to apply for grades 2-8 in the 2018-2019 academic year. Approximately three percent stated that the Arabic curriculum and textbooks were not in harmony, while approximately fifty five percent stated that it partially complied. About twenty-six percent stated that the books were visually sufficient, about twenty-one percent were not sufficient, and about fifty-three percent said they were partially sufficient. Approximately forty-two percent stated that textbooks were appropriate for readingcomprehension skills, about fourteen percent were unsuitable, and about forty-five percent said they were partially appropriate. Approximately forty-two percent stated that it was sufficient, about twenty-four percent stated that it was insufficient, and about forty-five percent stated that it was partially sufficient. Approximately thirty-four percent stated that they were inadequate, about sixteen percent said they were sufficient, and about fifty percent said they were partially sufficient. Approximately one in ten percent thought that textbooks were sufficient to improve their speaking skills, about forty-five percent were inadequate and about forty-five percent were partially sufficient. Approximately twenty-nine percent stated that it was a series in textbooks, about thirteen percent said it was not one, and about thirty-two percent said it was partly. About sixteen percent stated that the textbooks subject to the study were appropriate for language acquisition, about thirty-four percent were unsuitable, and about fifty percent said they were partially eligible.

\section{Results}

As with other foreign languages, it is necessary to know how to learn a foreign language. When learning Arabic in Turkey, in other words in a country where Arabic is not officially spoken techniques such as active learning, reinforcing what is learned, efficient and uninterrupted work, learning information in pieces, listening, reading and telling activities are thought to be beneficial.

According to the results of the research, it is possible to make the following suggestions about the programs to be written for grades 2-8:

- It would be more appropriate to write Arabic textbooks and textbooks which are the most important application tools during education by the same person or persons, if possible.

- It would be appropriate to equip the textbooks in accordance with today's technology.

- Visuality in textbooks is important. Especially for primary school students, books with visuals that will attract their attention should be written.

- Nowadays, internet and virtual environment is one of the rapidly developing communication too. Parallel to this, learning should be adapted to today's conditions. In general, foreign language education, in particular, Arabic language education during the use of virtual tools and equipment will be appropriate.

-One of the issues that the Ministry has to decide on teaching Arabic in primary and secondary schools is that the student does not change the foreign language she chooses in the second grade in later classes. 